Michał Długaszek, Anna Krywult, Alicja Daszyk, Katarzyna Dziadzio, Aleksandra Gacek, Katarzyna Zygmund, Adam Gąsior, Krzysztof Strojek

Śląski Uniwersytet Medyczny w Katowicach, Wydział Lekarski z Oddziałem Lekarsko-Dentystycznym w Zabrzu, III Katedra i Oddział Kliniczny Kardiologii — Oddział Kliniczny Chorób Wewnętrznych, Diabetologii i Schorzeń Metabolicznych, Śląskie Centrum Chorób Serca w Zabrzu

\title{
Lipohipertrofia - niedoceniane (ważne) skórne powikłanie insulinoterapii u pacjentów chorujących na cukrzycę
}

\author{
Lipohypertrophy - undervalued (important) cutaneous complication \\ of insulin therapy in diabetic patients
}

\section{STRESZCZENIE}

Wstęp. Leczenie cukrzycy (DM) stało się efektywniejsze po wprowadzeniu piór insulinowych, jednakże w miejscu wstrzyknięć zaobserwowano nowe powikłanie w postaci lipohipertrofii (LHT). W pracy podjęto próbę oceny częstości występowania i czynników ryzyka LHT u pacjentów leczonych insuliną.

Materiał i metody. Badaniem ankietowym objęto 130 pacjentów Wojewódzkiej Poradni dla Chorych na Cukrzycę w Zabrzu. W kwestionariuszu uwzględniono dane demograficzne, kliniczne, technikę insulinoterapii i wiedzę na temat LHT. Kryteria włączenia stanowiły: DM typu 1 i 2, insulinoterapia (> 2 lata) oraz stosowanie piór insulinowych. Lipohipertrofię definiowano jako stwierdzenie w badaniu fizykalnym występowania przerostu tkanki podskórnej w co najmniej 1 miejscu. Pacjentów podzielono na 2 grupy w zależności od średnicy i grubości LHT.

Wyniki. Lipohipertrofię stwierdzono u 78 pacjentów (60\%); zmiana w 1 miejscu występowała u 48 (61,5\%) z nich, a w więcej niż 1 miejscu u 30 (38,5\%) osób.

Adres do korespondencji:

Michał Długaszek

Śląski Uniwersytet Medyczny w Katowicach

Wydział Lekarski z Oddziałem Lekarsko-Dentystycznym w Zabrzu

III Katedra i Oddział Kliniczny Kardiologii

Śląskie Centrum Chorób Serca w Zabrzu

e-mail: michaldlugaszek@gmail.com

Diabetologia Kliniczna 2015, tom 4, 3, 104-109

DOI: 10.5603/DK.2015.0009

Copyright (C) 2015 Via Medica

Nadesłano: 28.04.2015

Przyjęto do druku: 14.06.2015
Wiedzę na temat LHT posiadało 78 (60\%) pacjentów, w tym w grupie z LHT tylko $47(60 \%)$ osób. Pacjenci z LHT istotnie dłużej chorowali na DM, dłużej stosowali insulinę i dłużej używali tej samej igły. Wyróżniali się oni ponadto wyższą glikemią na czczo i po posiłku, większym zapotrzebowaniem na insulinę i częściej zgłaszali epizody hipoglikemii. Używanie tej samej igły ponad 1 dzień, niezmienianie miejsca wstrzykiwania insuliny oraz stosowanie insuliny ludzkiej okazały się czynnikami ryzyka wystąpienia LHT.

Wnioski. Lipohipertrofia jest powszechnym skórnym powikłaniem stosowania piór insulinowych. Czynniki ryzyka, które uzyskano w tym badaniu, są modyfikowalne, co powinno być uwzględniane w codziennej praktyce klinicznej. (Diabet. Klin. 2015; 4, 3: 104-109)

Słowa kluczowe: cukrzyca, leczenie insuliną, lipohiertrofia

\section{ABSTRACT}

Introduction. The control of diabetes mellitus (DM) has been improved since the insulin pens were introduced into the diabetes treatment. In pen insulin injection site the new cutaneous complication - lipohypertrophy (LHT) was observed.

Objectives. The assessment of the occurrences and risk factors of LHT in insulin receive patients.

Patients and methods. 130 patients of the Regional Outpatient Diabetes Clinic in Zabrze were included to the study. The demographic, clinical characteristic, 
insulin therapy technique and knowledge about LHT were noticed in. The inclusion criteria: type 1 and 2 DM, > 2 years insulin therapy, insulin pen usage. LHT was defined as subcutaneous lump in $\geq 1$ place in physical examination. Patients were divided into 2 groups according to diameter and thickness of LHT. Results. LHT was observed in $78(60 \%)$ of patients, but $48(61.5 \%)$ patients developed LHT in 1 site, $30(38.5 \%)$ patients developed LHT in > 1 site. 78 (60\%) patients could defined LHT, but only $47(60 \%)$ in LHT group. Patients with LHT longer suffer from DM, longer receive insulin and longer use the same needle. They had higher fasting and postprandial glycaemia, higher insulin requirement and more often complain about hypoglycemia. In the multivariate analysis the independent factors for presence of LHT were: needle reuse $>1$ day, not changing sites of injection and human insulin usage.

Conclusions. LHT is a common cutaneous complication of insulin pen usage. Risk factors obtained in this study are modifiable and they should be taken into account in daily clinical practice. (Diabet. Klin. 2015; 4, 3: 104-109)

Key words: diabetes mellitus, insulin therapy, lipohypertrophy

\section{Wstęp}

Wprowadzenie insuliny do leczenia cukrzycy w 1922 r. uratowało życie wielu chorych [1]. Późne powikłania były i są przyczyną kalectwa, obniżenia komfortu życia i przedwczesnej umieralności chorych na cukrzycę [2]. Dzięki dużym próbom klinicznym i postępowi wiedzy na temat cukrzycy ustalono, że postępowaniem z wyboru w cukrzycy typu 1 (DM1, diabetes mellitus type 1) jest stosowanie wielokrotnych wstrzyknięć insuliny w modelu intensywnej insulinoterapii [1, 2]. Ten sposób leczenia naśladuje fizjologiczne wydzielanie insuliny w odpowiedzi na bodziec pokarmowy [3]. Decyzja o rozpoczęciu leczenia insuliną w cukrzycy typu 2 (DM2, diabetes mellitus type 2) jest nadal jednym z najpoważniejszych dylematów w diabetologii i wprowadzana jest w przypadku przeciwwskazań lub nieskuteczności leczenia za pomocą leków doustnych [4, 5]. Przez wiele lat od odkrycia insuliny iniekcje odbywały się z użyciem igieł wielokrotnego użytku, co powodowało powikłania w postaci zaników tkanki podskórnej — lipoatrofii (LA, lipoatrophy) [6]. W latach 90. wprowadzono do leczenia nową formę wstrzykiwaczy insuliny - pióra insulinowe i peny, które dzięki zaopatrzeniu w bardzo cienką igłę zniwelowały występowanie LA do 10\% [7]. W miejscu wielokrotnych wstrzyknięć insuliny za pomocą penów pojawiło się inne powikłanie w postaci przerostów tkanki podskórnej — lipohipertrofii (LHT, lipohypertrophy) [8]. Lipohipertrofia jest najczęstszym powikłaniem skórnym insulinoterapii i dotyczy $16-60 \%$ chorych przyjmujących insulinę [7-10]. Trwają dyskusje na temat LHT, gdyż jej etiologia jest najprawdopodobniej wieloczynnikowa [8]. Stosunkowo niedawne wprowadzenie do użycia piór insulinowych i wciąż niejasna etiologia LHT wydają się zasadne do podjęcia próby oceny częstości występowania tego zjawiska i określenia czynników predykcyjnych LHT.

\section{Materiał i metody}

Badaniem objęto grupę 130 osób chorych na cukrzycę, będących pacjentami Wojewódzkiej Poradni dla Chorych na Cukrzycę w Zabrzu. Ich dane antropometryczne i kliniczne pochodziły z dokumentacji medycznej prowadzonej w poradni, a pacjenci wyrazili zgodę na użycie ich danych. W tabeli 1 przedstawiono charakterystykę ogólną pacjentów. Do badania włączono osoby chorujące na cukrzycę (DM1 lub DM2), leczone insuliną od co najmniej 2 lat oraz stosujące pióra insulinowe. Lipohipertrofię definiowano jako stwierdzenie w badaniu fizykalnym (oglądanie i palpacja) przerostu tkanki podskórnej w co najmniej 1 miejscu. Lipohipertrofię klasyfikowano jako łagodną (średnica przerostu $<3 \mathrm{~cm}$, a grubość przerostu $<0,5 \mathrm{~cm}$ ) lub jako znaczną (średnica przerostu $>3 \mathrm{~cm}$, a grubość przerostu $>0,5 \mathrm{~cm}$ ) [9]. Oceniono także występowanie objawów hipoglikemii, którą definiowano jako co najmniej 1 epizod objawowej hipoglikemii w ciągu poprzedzającego miesiąca. Pacjenci zostali poproszeni o udzielenie odpowiedzi na pytania zawarte w ankiecie, które dotyczyły praktycznych elementów insulinoterapii (najczęstsze miejsce iniekcji insuliny, zastosowanie rotacji miejsc podczas wstrzyknięć, długość stosowanej igły, czas użycia 1 igły oraz bolesność iniekcji w LHT) oraz wiedzy o LHT. Zebrane dane poddano analizie statystycznej w programie STATISTICA 10.0 (StatSoft, Kraków, Polska). W celu porównania zmiennych ilościowych o rozkładach zbliżonych do normalnego zastosowano test t-Studenta. W przypadku zmiennych o rozkładzie niezbliżonym do normalnego użyto testu U Manna-Whitneya. Zmienne jakościowe porównywano testem $\chi^{2}$ Pearsona. Do sprawdzenia powiązania zmiennych zastosowano korelacje Spearmana. Do oceny wpływu zmiennych na wystąpienie LHT przeprowadzono analizę regresji logistycznej, a wyniki przedstawiono jako iloraz szans wraz z 95-procentowym przedziałem ufności.

\section{Wyniki}

W tabeli 2 przedstawiono porównania parametrów antropometrycznych i klinicznych pacjentów w zależno- 
Tabela 1. Charakterystyka badanej grupy chorych. Dane przedstawiono jako średnią \pm SD lub medianę (zakres)

\begin{tabular}{|c|c|c|c|}
\hline & $\begin{array}{l}\text { Populacja ogółem } \\
\qquad n=130\end{array}$ & $\begin{array}{l}\text { Osoby z cukrzycą typu } 1 \\
\qquad n=52\end{array}$ & $\begin{array}{l}\text { Osoby z cukrzycą typu } 2 \\
\qquad \mathrm{n}=78\end{array}$ \\
\hline Płeć K/M & $66 / 64$ & $30 / 22$ & $36 / 42$ \\
\hline Wiek [lata] & $58 \pm 16$ & $40 \pm 14$ & $66 \pm 8$ \\
\hline Wskaźnik masy ciała (BMI) $\left[\mathrm{kg} / \mathrm{m}^{2}\right]$ & $30,7 \pm 18,1$ & $24,9 \pm 4,1 * * *$ & $34 \pm 22,2$ \\
\hline Czas trwania cukrzycy [lata] & $20 \pm 10$ & $25 \pm 12^{*}$ & $17 \pm 7$ \\
\hline Czas trwania insulinoterapii [lata] & $14 \pm 12$ & $27 \pm 12^{* * *}$ & $8 \pm 6$ \\
\hline $\mathrm{HbA}_{1 \mathrm{c}}[\%]$ & $7,76 \pm 1,25$ & $7,62 \pm 1,48$ & $7,87 \pm 1,03$ \\
\hline $\begin{array}{l}\text { Stężenie glukozy na czczo [mg/dl], } \\
\text { średnia z } 3 \text { ostatnich pomiarów }\end{array}$ & $145 \pm 44$ & $150 \pm 58$ & $141 \pm 33$ \\
\hline $\begin{array}{l}\text { Stężenie glukozy po głównym posiłku [mg/dl], } \\
\text { średnia z } 3 \text { ostatnich pomiarów }\end{array}$ & $198 \pm 61,4$ & $197 \pm 80,6$ & $197 \pm 47$ \\
\hline Rodzaj insuliny & & & \\
\hline Analogowa [\%] & 44,5 & 54,5 & 33,9 \\
\hline Ludzka [\%] & 55,5 & 45,5 & 66,0 \\
\hline Liczba wstrzyknięć [j./dobę] & $4(1-6)$ & $4(4-6)$ & $3(1-4)$ \\
\hline Dawka insuliny [jm./dobę] & $67 \pm 28,6$ & $71,4 \pm 29,6$ & $63,1 \pm 26,9$ \\
\hline Dawka insuliny [jm./dobee/kg] & $0,82 \pm 0,34$ & $0,96 \pm 0,29 * *$ & $0,73 \pm 0,33$ \\
\hline
\end{tabular}

SD (standard deviation) - odchylenie standardowe; $p$ - prawdopodobieństwo; ${ }^{*} p<0,05$ vs. cukrzyca typu $2 ;{ }^{* *} p<0,005$ vs. cukrzyca typu $2 ;{ }^{* * *} p<0,001$ vs. cukrzyca typu 2

Tabela 2. Porównanie parametrów antropometrycznych i klinicznych u pacjentów z obecnością lub brakiem lipohipertrofii. Dane przedstawiono jako średnie \pm SD

\begin{tabular}{|c|c|c|c|}
\hline & $\begin{array}{l}\text { Obecna lipohipertrofia } \\
\qquad n=78(60 \%)\end{array}$ & $\begin{array}{c}\text { Brak lipohipertrofii } \\
n=52(40 \%)\end{array}$ & R Spearman \\
\hline Wiek [lata] & $55 \pm 15$ & $58 \pm 16$ & $-0,11$ \\
\hline Wskaźnik masy ciała (BMI) $\left[\mathrm{kg} / \mathrm{m}^{2}\right]$ & $28,1 \pm 5,2$ & $29,9 \pm 6,2$ & $-0,12$ \\
\hline $\mathrm{HbA}_{1 \mathrm{c}}[\%]$ & $7,9 \pm 1,3$ & $7,5 \pm 1,1$ & 0,18 \\
\hline Czas trwania cukrzycy [lata] & $22 \pm 11$ & $17 \pm 9^{* *}$ & $0,25^{\#}$ \\
\hline Czas trwania insulinoterapii [lata] & $17 \pm 5$ & $10 \pm 3^{*}$ & $0,34^{\# \# \#}$ \\
\hline Glikemia na czczo [mg/dl] & $150 \pm 42$ & $128 \pm 35^{*}$ & $0,29^{\# \#}$ \\
\hline Glikemia po głównym posiłku [mg/dl] & $205 \pm 67$ & $164 \pm 27^{* * *}$ & $0,46^{\# \# \#}$ \\
\hline Liczba wstrzyknięć [j./dobę] & 4 & 4 & 0,15 \\
\hline Czas stosowania tej samej igły [dni] & $5 \pm 1$ & $4 \pm 1^{* * *}$ & $0,41^{\# \# \#}$ \\
\hline Dawka insuliny [jm.//kg/dobę] & $0,88 \pm 0,32$ & $0,73 \pm 0,34^{*}$ & $0,29^{\# \#}$ \\
\hline
\end{tabular}

SD (standard deviation) — odchylenie standardowe; $p$ - prawdopodobieństwo; ${ }^{*} p<0,01$ vs. lipohipertrofia; ${ }^{* *} p<0,05$ vs. lipohipertrofia; ${ }^{* * *} p<0,001$ vs. lipohipertrofia; ${ }^{\mathrm{p}}<0,05 ;{ }^{\# \#} \mathrm{p}<0,01 ;{ }^{\# \# \#} \mathrm{p}<0,001$

ści od obecności LHT. Zgodnie z przyjętymi kryteriami LHT stwierdzono u 78 pacjentów (60\%): 48 pacjentów $(61,5 \%)$ z LHT wykazywało zmianę w 1 miejscu, a u 30 pacjentów (38,5\%) opisano LHT w więcej niż 1 miejscu. W 40 przypadkach $(51,2 \%)$ LHT opisano jako łagodną, a u 38 pacjentów (48,8\%) jako znaczną. Tylko 6 pacjentów skarżyło się na bolesność wkłucia w LHT. Spośród wszystkich respondentów 78 (60\%) wiedziało, czym jest LHT, natomiast w grupie z LHT taką wiedzę posiadało 47 pacjentów (60\%).
Podaż insuliny na dobę w grupie pacjentów z LHT była znacznie większa niż pacjentów bez LHT, zauważono także istotną korelację pomiędzy zapotrzebowaniem na insulinę a wystąpieniem LHT. Opisywane grupy różniły się również pod względem czasu trwania cukrzycy oraz czasu trwania insulinoterapii. Ważną różnicę zaobserwowano w pomiarze średnich glikemii na czczo oraz w 2 godziny po głównym posiłku, przy czym obie wartości były wyższe w grupie chorych z LHT i istotnie z nią korelowały. Pacjenci z LHT częściej zgłaszali wystę- 
Tabela 3. Tabela liczności chorych z i bez lipohipertrofii (LHT)

\begin{tabular}{llcc}
\hline & & \multicolumn{2}{c}{ LTH } \\
\cline { 3 - 4 } Zmiana miejsca wstrzyknięcia & & Obecna & Nieobecna \\
\cline { 3 - 3 } Rodzaj stosowanej insuliny & Tak & $12(9 \%)$ & $22(17 \%)$ \\
Obecność hipoglikemii & Nie & $21(49 \%)^{*}$ & $32(25 \%)$ \\
& Analogowa & $60(46 \%)^{* *}$ & $18(14 \%)$ \\
Cukrzyca & Ludzka & $57(44 \%)^{* *}$ & $14(11 \%)$ \\
& Tak & $21(16 \%)$ & $38(29 \%)$ \\
& Nie & $38(29 \%)$ & $14(11 \%)$ \\
\hline
\end{tabular}

LHT występowała istotnie częściej u chorych niezmieniających miejsc wstrzyknięć insuliny $\left({ }^{*} p<0,005\right)$. Stwierdzono, że rodzaj insuliny miał wpływ na wystąpienie LHT (częściej w przypadku insuliny ludzkiej — **p $<0,001$ ). Wśród chorych, u których w ciągu ostatniego miesiąca wystąpiły epizody hipoglikemii, istotnie częściej występowała LHT $(* * p<0,001)$. Typ cukrzycy nie miał wpływu na częstość LHT

Tabela 4. Analiza regresji logistycznej zmiennych wpływających na występowanie lipohipertrofii

\begin{tabular}{lccc}
\hline Badany parametr & OR & $95 \% \mathrm{Cl}$ & $\mathbf{p}$ \\
\hline Stosowanie tej samej igły dłużej niż 1 dzień & 1,62 & $1,14-2,30$ & $<0,05$ \\
Niezmienianie miejsca wstrzyknięcia & 4,13 & $1,48-11,47$ & $<0,005$ \\
Stosowanie insuliny ludzkiej & 3,53 & $1,1-12,48$ & $<0,05$ \\
Cukrzyca typu 1 & 0,36 & $0,05-2,29$ & $>0,05$ \\
1 rok stosowania insuliny & 1,05 & $0,98-1,14$ & $>0,05$ \\
Każde kolejne wstrzyknięcie na dobę & 0,87 & $0,36-2,11$ & $>0,05$ \\
Długość stosowanej igły & 0,57 & $0,25-1,33$ & $>0,05$ \\
\hline
\end{tabular}

OR (odds ratio) - iloraz szans; Cl (confidence interval) - przedział ufności; $\mathrm{p}$ - prawdopodobieństwo

powanie hipoglikemii. Pomiędzy badanymi grupami nie było różnic w wieku, wskaźniku masy ciała (BMI, body mass index), stężeniu hemoglobiny glikowanej $\left(\mathrm{HbA}_{1 \mathrm{c}}\right)$ i liczbie wstrzyknięć insuliny na dobę.

W tabeli 3 przedstawiono liczebność pacjentów w zależności od występowania LHT. W tabeli 4 zestawiono wyniki analizy regresji logistycznej czynników predysponujących do LHT. Pacjenci z LHT używali dłużej tej samej igły, co powoduje istotny wzrost ryzyka wystąpienia LHT o 62\% na każdy 1 dodatkowy dzień. Ponadto czas stosowania tej samej igły istotnie korelował z występowaniem LHT. Przy używaniu tej samej igły przez 4 dni ryzyko wystąpienia LHT wzrasta ponad 4-krotnie, a przy 7-dniowym stosowaniu ryzyko wzrasta prawie 18-krotnie (w porównaniu z używaniem tej samej igły przez 1 dzień). Kolejnym ważnym czynnikiem ryzyka wystąpienia LHT jest zmiana miejsca wstrzykiwania insuliny. W przypadku braku zmiany miejsca wstrzyknięcia ryzyko wystąpienia LHT wzrasta ponad 4-krotnie. Trzecim istotnym czynnikiem wpływającym na wystąpienie LHT jest rodzaj stosowanej insuliny, gdyż podawanie insuliny ludzkiej wiąże się z ponad 3,5-krotnym ryzykiem LHT. Pozostałe czynniki (typ cukrzycy, czas jej trwania, liczba wstrzyknięć na dobę, długość igły oraz zapotrzebowanie dobowe na insulinę) w stworzonym modelu regresji logistycznej okazały się nieistotne dla wystąpienia LHT.

\section{Dyskusja}

Prawidłowa technika wstrzykiwania insuliny jest związana z przestrzeganiem przez pacjenta chorego na cukrzycę zaleceń dotyczących sposobu iniekcji. Błędy ze strony pacjenta mogą doprowadzić do ujawnienia się skórnych powikłań insulinoterapii. Obecnie najczęściej obserwuje się LHT, która w badanej grupie pacjentów występowała u $60 \%$ osób. Zarówno Polskie Towarzystwo Diabetologiczne, jak i Europejskie Towarzystwo Diabetologiczne w swoich zaleceniach nie podejmują problemu LHT, a dopiero jeden z rozdziałów w brytyjskich wytycznych jest poświęcony LHT [4, 11, 12]. Rozpoznanie LHT opiera się na badaniu fizykalnym miejsc wstrzykiwania insuliny. W początkowym stadium pod skórą wyczuwalny jest spoisty guz, który w miarę narastania może być obserwowany jako miejscowy guz uwypuklający powłoki. Patofizjologia LHT jest złożona. W wyniku anabolicznego oraz lipogenicznego działania 
insuliny w obrębie wielokrotnych wstrzyknięć dochodzi do miejscowego wzrostu objętości i zwiększenia liczby adipocytów, co przyczynia się do wzrostu spoistości tkanki podskórnej, a następnie jej zgrubienia [8]. W badaniu histopatologicznym LHT zauważono zmniejszoną ilość naczyń krwionośnych z przerostem tkanki włóknistej oraz ogniskami martwicy [13]. Znajomość budowy guzka LHT staje się kluczowa do zrozumienia ryzyka zaburzeń metabolicznych, jakie niesie za sobą wstrzykiwanie insuliny w LHT.

Wysoka częstość LHT u osób chorych na cukrzycę wskazuje na powszechność problemu w tej grupie. Niestety u znacznej części pacjentów LHT obserwuje się w kilku miejscach, co prawdopodobnie wynika z preferencji pacjentów do tych właśnie miejsc. Do tej pory tylko w kilku pracach podjęto próbę klasyfikacji zmian LHT. W metodyce pracy użyto dwustopniową klasyfikację LHT, którą zaproponował Hauner i wsp. [9]. W innym badaniu Overland i wsp. zasugerowali, aby zmiany przerostowe większe niż $5 \mathrm{~cm}$ uznawać za znaczące klinicznie [14]. Konieczne jest stworzenie ogólnie akceptowanej klasyfikacji zmian o charakterze LHT w celu ujednolicenia badań i porównania otrzymywanych wyników.

Rozpowszechnienie wiedzy o LHT wśród pacjentów przyjmujących insulinę jest zadziwiająco dobre, lecz interesujący jest fakt, że tylko $60 \%$ pacjentów z LHT wiedziało, czym jest posiadana zmiana. Dlatego też wiedzę o LHT należy rozpowszechnić, aby pacjenci byli świadomi, jakie niesie ona za sobą konsekwencje.

Wyniki przeprowadzonego badania pozwolity na zidentyfikowanie trzech głównych czynników ryzyka LHT. Brak częstej wymiany igły w przebadanej grupie mógł wynikać zarówno z przyczyn ekonomicznych, jak i z braku wiedzy na temat LHT lub bagatelizowania jej problemu. Podobne wyniki otrzymano w dwóch badaniach przeprowadzonych w populacji europejskiej i chińskiej $[15,16]$. W pierwszym z nich wykazano, że u pacjentów, którzy stosowali więcej niż 1 raz tę samą igłę, średnie ryzyko LHT wzrastało o 31\%, natomiast w opisanym w niniejszej pracy badaniu wzrost ryzyka obliczono na $62 \%$, ale na każdy dodatkowy dzień stosowania igły. Różnice dotyczące zmieniania igły u pacjentów diabetologicznych w krajach europejskich mogą mieć związek z niejednakową dostępnością do igieł w badanych krajach. W Chinach wielokrotność użycia tej samej igły wynikała z przyczyn ekonomicznych. Odmienne wyniki prezentuje mniejsze badanie przeprowadzone w 2013 r. w Irlandii, które nie potwierdza związku między wzrostem ryzyka wystąpienia LHT a stosowaniem tej samej igły więcej niż 1 raz [17]. Jednakże badaniem objęto znacznie mniejszą i dość jednorodną grupę chorych, w przeciwieństwie do cytowanych powyżej badań. Igła powinna być stosowana jednorazowo, nie tylko ze względu na ryzyko zakażeń, ale także ze względu na ścieralność jej końca. Igła użyta wielokrotnie zmienia swój kształt i powoduje mikrourazy, co sprzyja powstaniu stanu zapalnego [18], czemu z kolei towarzyszy uwolnienie szeregu cytokin wzrostowych; zejściem stanu zapalnego jest natomiast proces włóknienia, co prawdopodobnie prowadzi do LHT. Kolejnym czynnikiem związanym z LHT jest rotacja miejsca wstrzyknięcia insuliny. Brak dbałości o rotację miejsc wstrzykiwania insuliny okazuje się niezależnym czynnikiem ryzyka wystąpienia LHT także w piśmiennictwie [9]. Spośród wszystkich dozwolonych miejsc wstrzykiwania insuliny najczęściej wybierany jest brzuch, co może się wiązać z mniejszą bolesnością podawania insuliny w brzuch w porównaniu z podaniem w udo [18]. Brzuch jest również preferowanym miejscem podawania insulin krótkodziałających. Brak zmiany miejsca iniekcji lub celowe wybieranie miejsca ze zmianą LHT do podania insuliny może również wynikać z braku bolesności podania w zmiany LHT (w badanej grupie tylko kilku chorych doświadczało bólu przy podaniu insuliny w zmianę LHT). Trzecim wyodrębnionym czynnikiem ryzyka LHT jest rodzaj stosowanej insuliny, co także zaobserwowano w innych badaniach [9]. Wraz z wprowadzeniem do lecznictwa insuliny ludzkiej większym problemem niż LA wydaje się LHT [19]. Pomimo stosowania insuliny ludzkiej i poprawy czystości insuliny częstość występowania LHT pozostaje nadal wysoka [20]. Wydaje się, że istotna różnica $w$ rozwoju LHT przy stosowaniu różnych typów insuliny wynika z szybkości wchłaniania insuliny z tkanki podskórnej, co wiąże się z długością kontaktu insuliny $z$ adipocytami oraz tym samym z rozwojem reakcji immunologicznej na lek. Istnieją doniesienia, że zmiana insuliny z ludzkiej na ultraszybkodziałającą insulinę lispro powoduje rzadsze występowanie LHT [20]. Lispro wchłania się szybciej i krócej kontaktuje się z komórkami tłuszczowymi tkanki podskórnej [20].

Wykazano, że wystąpienie LHT jako skórnego powikłania insulinoterapii znacząco wpływa na pogorszenie procesu wchłaniania insuliny podawanej w przerost $[21,22]$. Prowadzi to do gorszego efektu jej działania i skutkuje wolniejszym spadkiem glikemii po posiłku, co zaobserwowano u badanych pacjentów. Okazuje się również, że występowanie LHT wiąże się z wyższymi stężeniami glukozy na czczo. Prawdopodobnie przyczyną powyższego problemu jest podawanie insuliny nocnej w zmianę LHT. Duże fluktuacje średnich glikemii u pacjentów z LHT zaobserwowali także inni badacze [19]. Zaburzenie wchłaniania insuliny wiąże się również z częstszym występowaniem hipoglikemii u pacjentów z LHT [23]. Podając insulinę w zmianę LHT, pacjenci muszą ustalić większą dawkę insuliny, aby uzyskać po- 
żądany spadek glikemii. Natomiast gdy zmienią miejsce wstrzyknięcia okazuje się, że ustalona wcześniej dawka nadmiernie obniża stężenia glukozy we krwi z powodu innej dynamiki wchłaniania z niezmienionej tkanki podskórnej. W badaniu zaobserwowano również, że u pacjentów z LHT dobowe zapotrzebowanie na insulinę jest istotnie wyższe niż u osób, u których nie rozwinęło się to powikłanie, co może wynikać z opisanego wcześniej gorszego jej wchłaniania z miejsca przerostu. Obserwowane prawidłowości nie są czynnikami ryzyka LHT, lecz zdają się być jej skutkiem. Potwierdza to zauważone zmniejszenie zapotrzebowania na insulinę u pacjentów, u których udało się osiągnąć zmniejszenie LHT poprzez prawidłową technikę wstrzyknięć, ze zwróceniem uwagi na zmianę miejsca wstrzyknięcia [24]. Wskazuje to na istotę powiązania wystąpienia LHT ze złym wyrównaniem pacjenta diabetologicznego. Badania wskazują na występowanie wyższych wartości $\mathrm{HbA}_{1 c}$ w przypadku rozwinięcia LHT, jednak w tym badaniu tego nie zaobserwowano [25]. Nie bez znaczenia jest też aspekt ekonomiczny zmniejszenia zapotrzebowania na insulinę, prowadzący do mniejszych wydatków pacjenta. Wpływ dłuższego czas trwania cukrzycy oraz insulinoterapii na wystąpienie LHT jest uzasadniony [23].

Ze względu na wcześniejsze wprowadzenie insuliny do terapii w DM1 niż w DM2 analizowano osobno częstość występowania LHT w obu grupach. W przeciwieństwie do danych uzyskanych z poprzednich badań nad LHT [9] nie zauważono różnic między częstością występowania przerostów u pacjentów z DM1 i DM2 (29\% vs. 31\%), jednak większy odsetek pacjentów z DM1 cierpiał dodatkowo na LHT w porównaniu z osobami z DM2. Wcześniejsze badania wykazały, że LHT częściej występuje w DM1, co może być związane z dłuższą terapią insuliną w tej grupie pacjentów oraz obecnością przeciwciał przeciwinsulinowych. Przypuszcza się również, że powodem częstszej LHT u pacjentów z DM1 jest ich BMI, a co się z tym wiąże - stopień rozwinięcia tkanki tłuszczowej. Do podobnych wniosków doszli Omar i wsp., analizując grupę dzieci chorujących na DM1, również pod względem BMI [26]. U osób szczupłych łatwiej ocenić już drobne zmiany, które przez długi czas pozostają niezauważone u otyłych.

\section{Wnioski}

Lipohipertrofia jest powszechnym powikłaniem insulinoterapii i może mieć wpływ na przebieg leczenia cukrzycy. Należy poszerzyć program edukacji chorych o elementy, które zmniejszą ryzyko wystąpienia LHT.

\section{Oświadczenie o konflikcie interesów}

Autorzy nie zgłaszają konfliktu interesów.

\section{PIŚMIENNICTWO}

1. Fry A. Insulin delivery device technology 2012: where are we after 90 years? J. Diabetes Sci. Technol. 2012; 6: 947-953.

2. Liebl A., Khunti K., Orozco-Beltran D., Yale J.-F. Health Economic Evaluation of Type 2 Diabetes Mellitus: A Clinical Practice Focused Review. Clin. Med. Insights Endocrinol. Diabetes 2015; 8: 13-19.

3. Raciti G.A., Longo M., Parrillo L. i wsp. Understanding type 2 diabetes: from genetics to epigenetics. Acta Diabetol. 2015 Apr 5 [Epub ahead of print].

4. Polish Diabetes Association. [Clinical guidelines for the management of patients with diabetes by 2015. Position of the Polish Society of Diabetes]. Clinical Diabetology 2015; 4: 1-73.

5. American Diabetes Association. Standards of medical care in diabetes-2015: summary of revisions. Approaches to Glycemic Treatment. Diabetes Care 2015; 38: 41-48.

6. Cortés V.A., Fernández-Galilea M. Lipodystrophies: adipose tissue disorders with severe metabolic implications. J. Physiol. Biochem. 2015 Apr 2 [Epub ahead of print].

7. Holstein A., Stege H., Kovacs P. Lipoatrophy associated with the use of insulin analogues: a new case associated with the use of insulin glargine and review of the literature. Expert Opin. Drug Saf. 2010; 9: 225-231.

8. Blanco M., Hernández M.T., Strauss K.W., Amaya M. Prevalence and risk factors of lipohypertrophy in insulin-injecting patients with diabetes. Diabetes Metab. 2013; 39: 445-453.

9. Hauner H., Stockamp B., Haastert B. Prevalence of lipohypertrophy in insulin-treated diabetic patients and predisposing factors. Exp. Clin. Endocrinol. Diabetes 1996; 104: 106-110.

10. Hambridge K. The management of lipohypertrophy in diabetes care. Br. J. Nurs. 2007; 16: 520-524.

11. Sibal L., Home P.D. Management of type 2 diabetes: NICE guidelines. Clin. Med. 2009; 9: 353-357.

12. Rydén L., Grant P.J., Anker S.D. i wsp. ESC Guidelines on diabetes, pre-diabetes, and cardiovascular diseases developed in collaboration with the EASD: the Task Force on diabetes, pre-diabetes, and cardiovascular diseases of the European Society of Cardiology (ESC) and developed in collaboratio. Eur. Heart J. 2013; 34: 3035-3087.

13. Fujikura J., Fujimoto M., Yasue S. i wsp. Insulin-induced lipohypertrophy: report of a case with histopathology. Endocr. J. 2005; 52: 623-628.

14. Overland J., Molyneaux L., Tewari S. i wsp. Lipohypertrophy: does it matter in daily life? A study using a continuous glucose monitoring system. Diabetes Obes. Metab. 2009; 11: 460-463.

15. Strauss K., Gols H.D., Hannet I. i wsp. A pan-European epidemiologic study of insulin injection technique in patients with diabetes. Pr. Diab. Int. 2002; 19: 71-76.

16. Ji J., Lou Q. Insulin pen injection technique survey in patients with type 2 diabetes in mainland China in 2010. Curr. Med. Res. Opin. 2014; 6: 1087-1093.

17. Cunningham M.T., McKenna M.J. Lipohypertrophy in insulin-treated diabetes: Prevalence and associated risk factors. J. Diabetes Nur. 2013; 17: 340-343.

18. Heise T., Nosek L., Dellweg S. i wsp. Impact of injection speed and volume on perceived pain during subcutaneous injections into the abdomen and thigh: a single-centre, randomized controlled trial. Diabetes, Obes. Metab. 2014; 16: 971-976.

19. Chowdhury T.A. Poor glycaemic control caused by insulin induced lipohypertrophy. BMJ 2003; 327: 383-384.

20. Roper N.A., Bilous R.W. Resolution of lipohypertrophy following change of short-acting insulin to insulin lispro (Humalog ${ }^{\circledR}$ ). Diabet. Med. 1998; 15: 1063-1064.

21. Johansson U.-B., Amsberg S., Hannerz L. i wsp. Impaired absorption of insulin aspart from lipohypertrophic injection sites. Diabetes Care 2005; 28: 2025-2027.

22. Young R.J., Hannan W.J., Frier B.M. i wsp. Diabetic lipohypertrophy delays insulin absorption. Diabetes Care 1984; 7: 479-480.

23. Vardar B., Kızılcı S. Incidence of lipohypertrophy in diabetic patients and a study of influencing factors. Diabetes Res. Clin. Pract. 2007: 77: 231-236.

24. Berard L., Cameron B. Injection Technique Practices in a Population of Canadians with Diabetes: Results from a Recent Patient/Diabetes Educator Survey. Can. J. Diabetes 2015; 39: 146-151.

25. Hajheydari Z., Kashi Z., Akha O., Akbarzadeh S. Frequency of lipodystrophy induced by recombinant human insulin. Eur. Rev. Med. Pharmacol. Sci. 2011; 15: 1196-1201.

26. Omar M.A., El-Kafoury A.A., El-Araby R.I. Lipohypertrophy in children and adolescents with type 1 diabetes and the associated factors. BMC Res. Notes 2011; 4: 290 